\title{
Design and Implement Whitening Teeth Kit Using Normal Toothpaste
}

\section{Fadia Noori Al-Nuaimy ${ }^{1}$ Ali Saadi Hamza}

\section{Ibrahim Amer Ibrahim ${ }^{1}$ Adile Faeq Naji}

\author{
1 Biomedical Engineering Dept. \\ Al-Khwarizmi College of engineering \\ University of Baghdad \\ Fadianoori@yahoo.com ${ }^{1}$ iai.power@gmail.com ${ }^{2}$
}

DOI $<10.26821 /$ IJSHRE.8.2.2020.8203>

\begin{abstract}
The white teeth are a dream for everyone and are an important and essential part of facial parts. The use of whitening teeth devices and whitening chemical material substances in clinics is a very expensive process and needs a long time and many visits to cosmetic clinics. In addition to that, the use of high and long-time UV light could lead to serious problems to a person like sensitivity and maybe for long-time use could lead to cancer because the oral tissues are very sensitive. Whatever the case it is a good idea if we can white our teeth when we are in our homes. The proposed device is using the normal blue Light Emitting Diode (LED) light instead of Ultraviolet (UV) light. Moreover, the device used normal teeth past for doing teeth whiting process. This project presents a device for bleaching teeth (small in size, mobile, cheap and efficient) in addition to using a normal toothpaste instead of using complex chemical agents that could harm the person. We did many tests to check the ability of this device to remove discoloration of teeth and we got brilliant results.
\end{abstract}

Keyword: LED; Toothpaste; Whiting; Bleaching; Shade Guide.

\section{INTRODUCTION}

Corrective dentistry became one of the main demands and worries for a large portion of the worldwide population. More white teeth are accepted to be related to wellbeing or excellence. People are requesting an ideal grin incredibly. Tooth staining causes have various etiologies this can be because of inner staining or outer staining or a mix of both.

Tooth/staining can be treated by various treatment approaches beginning from the least obtrusive strategy, for example, brightening toothpaste, proficient cleaning (scaling and cleaning) to evacuate surface stains and inner writings of non-crucial teeth [1].

\subsection{Tooth discoloration:}

Tooth discoloration is abnormal tooth color, hue or translucency. The external discoloration is the accumulation of stains on the tooth surface. The internal discoloration is due to the absorption of pigment particles into tooth structure. Sometimes there are several different co-existent factors responsible for discoloration [2-5].

\subsection{Teeth whitening:}

Tooth brightening helps teeth and assists with expelling stains and staining. Brightening is among the most well-known corrective dental methods since it can incredibly improve how the teeth look. Most dental specialists perform the tooth brightening process usually. Brightening is not a one - time method. It should be rehashed now and again to keeping up the more splendid whiting. There are two primary sorts of brightening techniques. Essential brightening is performed on teeth that have live nerves. Non-crucial brightening 
is done on a tooth that has had root treatment and never again has an alive nerve [6][7].

\subsection{LED Light Whiten Teeth Device}

It is a gadget that discharges noticeable light when provided with an electrical flow. Regularly the light is solitary lighting that can be anyplace among red and blue-violet on the noticeable light scale. LED lights can be extraordinary and frequently more splendid than their halogen or shining light partners. They are likewise much cooler as they have productive warmth dispersing structures. Driven lights needn't bother with a lot of intensity however are profoundly proficient and keep going quite a while, especially in contrast with other light sources. They don't have a warm-up time, so they switch on at their most elevated power straight away. They are a type of obvious light, so they are not a kind of ionizing radiation, which implies they can't cause cell changes and consequently can't cause malignancy. It is a more secure option in contrast to UV light for use in teeth brightening methodology [8].

\subsection{Goals and Future Plans}

In this project, we will make a tooth whitening device for home use. It is converting the bleaching device in hospitals and dental beauty centers into a small, simple, easy to use and safer device for home uses with a little cost.

The study work on the design of the device with control over the intensity of lighting and time for the purpose of studying their effect on bleaching in order to find the intensity and time for each case of yellowing teeth. This can be done using regular toothpaste contains a low proportion of hydrogen peroxide because of the percentage of its damage and cause allergic to the gum. Also, this toothpaste will give the same effective bleaching.

\section{THEORETICAL BACKGROUND}

This chapter shows the literature review and the relation between chemical substance and light, principles of teeth whitening and the method used for treatment.

\subsection{Literature review}

Table (1) summarizes the recent important researches that focus on whitening or bleaching the teeth at home and office.

Table 1. Historical methods to improve teeth bleaching

\begin{tabular}{|c|c|c|}
\hline Objective & Title & Reference \\
\hline $\begin{array}{l}\text { In this double-blind, placebo-controlled } \\
\text { clinical trial, statistically significant } \\
\text { tooth whitening was evident after three } \\
\text { days' treatment with } 10 \% \text { hydrogen } \\
\text { peroxide whitening strips, and color } \\
\text { improved with continued usage over } \\
\text { seven days. }\end{array}$ & $\begin{array}{l}\text { Placebo-controlled } \\
\text { clinical trial evaluating a } \\
10 \% \text { hydrogen peroxide } \\
\text { whitening strip }\end{array}$ & $\begin{array}{l}\text { M.L.Barker, Robert W } \\
\text { Gerlach, Paul A Sagel, } \\
\text { Katherine A Karpinia, } \\
\text { Ingvar Magnusson } \\
\text { (2004) }\end{array}$ \\
\hline $\begin{array}{l}\text { Rapid innovation in vital bleaching } \\
\text { continues to expand the number of } \\
\text { treatment options available to patients, } \\
\text { particularly in the area of at-home } \\
\text { whitening. The development of } \\
\text { bleaching strips represented a new } \\
\text { paradigm in the delivery of peroxide. }\end{array}$ & \begin{tabular}{lcr}
\multicolumn{2}{l}{ Professional } & vital \\
bleaching & using a thin \\
and & concentrated \\
peroxide & gel & on \\
whitening & strips: An \\
integrated & \multicolumn{2}{c}{ clinical } \\
summary & &
\end{tabular} & $\begin{array}{l}\text { M.L.Barker, Robert W } \\
\text { Gerlach (2004) }\end{array}$ \\
\hline $\begin{array}{l}\text { Vital bleaching with } 10 \% \text { hydrogen } \\
\text { peroxide strips at one week was as } \\
\text { effective as } 6 \% \text { hydrogen peroxide } \\
\text { strips used for two weeks. }\end{array}$ & $\begin{array}{lr}\text { Randomized } & \text { controlled } \\
\text { trial of } 10 \% & \text { hydrogen } \\
\text { peroxide } & \text { whitening } \\
\text { strips. } & \\
\end{array}$ & $\begin{array}{l}\text { M.L.Barker, Robert W } \\
\text { Gerlach, Paul A Sagel, } \\
\text { Hooman Shahidi(2005) }\end{array}$ \\
\hline $\begin{array}{l}\text { New formulation has been shown, in } \\
\text { these studies, to combine low }\end{array}$ & $\begin{array}{l}\text { The stain removal } \\
\text { performance of a new }\end{array}$ & $\begin{array}{l}\text { K S Price, M A Wicks, } \\
\text { Jonathan Creeth (2006) }\end{array}$ \\
\hline
\end{tabular}


Volume 8 Issue 2 February 2020

\begin{tabular}{|c|c|c|}
\hline $\begin{array}{l}\text { abrasively with an in vitro stain } \\
\text { removal performance comparable with } \\
\text { that of benchmark marketed pastes. }\end{array}$ & $\begin{array}{l}\text { anti-hypersensitivity } \\
\text { dentifrice }\end{array}$ & \\
\hline $\begin{array}{l}\text { These results confirm that hydrogen } \\
\text { peroxide whitening strips do not } \\
\text { produce changes in surface/subsurface } \\
\text { histomorphology, } \\
\text { microhardness and micro-chemical } \\
\text { composition of teeth. }\end{array}$ & $\begin{array}{l}\text { Effects of elevated } \\
\text { hydrogen peroxide 'strip' } \\
\text { bleaching on surface and } \\
\text { subsurface enamel } \\
\text { including subsurface } \\
\text { histomorphology }\end{array}$ & $\begin{array}{l}\text { Heinz Duschner , } \\
\text { Malgorzata } \\
\text { Klukowska , Donald J } \\
\text { White , Hermann } \\
\text { Götz(2007) }\end{array}$ \\
\hline $\begin{array}{l}\text { Extra White does not have any } \\
\text { deleterious effects on sound human } \\
\text { enamel microhardness after an extended } \\
\text { and exaggerated simulated } 8 \text { weeks of } \\
\text { product use. }\end{array}$ & $\begin{array}{l}\text { Evaluation of a } 6 \% \\
\text { hydrogen peroxide tooth- } \\
\text { whitening gel on enamel } \\
\text { microhardness after } \\
\text { extended use }\end{array}$ & $\begin{array}{l}\text { Mariarosaria Toteda, } \\
\text { Carole J Philpotts , } \\
\text { Trevor F Cox, Andrew } \\
\text { Joiner.(2008) }\end{array}$ \\
\hline $\begin{array}{l}\text { The source of irradiation is more } \\
\text { relevant than the bleaching agent for } \\
\text { efficient tooth whitening. In addition, } \\
\text { photoactivation with LED was found to } \\
\text { be the best choice: it yielded significant } \\
\text { change in color with only a minor } \\
\text { increase in pulpal temperature }\end{array}$ & $\begin{array}{l}\text { Influence of the Light } \\
\text { Source and Bleaching } \\
\text { Gel on the Efficacy of } \\
\text { the Tooth Whitening } \\
\text { Process }\end{array}$ & $\begin{array}{l}\text { Arantza Domínguez, } \\
\text { Juan Antonio García, } \\
\text { Angel Costela , Clara } \\
\text { Gómez.(2010) }\end{array}$ \\
\hline $\begin{array}{l}\text { Conventional whitening agents (G1; } \\
\mathrm{G} 2) \text { and the gel with } \mathrm{Ca}(\mathrm{G} 6) \text {, caused } \\
\mathrm{KHN} \text { decrease (P< 0.05). The } \\
\text { remineralizing and whitening agents } \\
\text { with Ca and PO4 (G3; G4; G5) did not } \\
\text { change KHN. A change of morphology } \\
\text { was observed on enamel and dentin } \\
\text { surfaces in G1; G2; G5. }\end{array}$ & $\begin{array}{l}\text { Influence of five home } \\
\text { whitening gels and a } \\
\text { remineralizing gel on the } \\
\text { enamel and dentin } \\
\text { ultrastructure and } \\
\text { hardness }\end{array}$ & $\begin{array}{lr}\text { Helena } & \text { Burlamaqui } \\
\text { Pinheiro, } & \text { Paulo } \\
\text { Eduardo } & \text { Capel } \\
\text { Cardoso.(2011) } & \end{array}$ \\
\hline $\begin{array}{l}\text { The aim of this in vitro study was to } \\
\text { evaluate the colour stability of } \\
\text { bleaching after light activation with } \\
\text { halogen unit, laser, LED unit or } \\
\text { chemical activation up to } 3 \text { months after } \\
\text { treatment. }\end{array}$ & $\begin{array}{l}\text { Efficacy of tooth } \\
\text { bleaching with and } \\
\text { without light activation } \\
\text { and its effect on the pulp } \\
\text { temperature: An in vitro } \\
\text { study. }\end{array}$ & $\begin{array}{l}\text { Petra Hahn, Nina } \\
\text { Schondelmaier, Martin } \\
\text { Wolkewitz, Markus } \\
\text { Altenburger, Olga } \\
\text { Polydorou.(2012) }\end{array}$ \\
\hline $\begin{array}{l}\text { The aim of this study was to evaluate } \\
\text { the permeability (PE), microhardness } \\
(\mathrm{KHN}) \text {, and mineral change in enamel } \\
\text { after LED/laser activated in-office } \\
\text { bleaching. }\end{array}$ & $\begin{array}{lr}\text { Effects of } & \begin{array}{r}\text { Light } \\
\text { Activated } \\
\text { In-office }\end{array} \\
\text { Bleaching } & \text { on } \\
\text { Permeability, } & \\
\text { Microhardness, } & \\
\text { Mineral Content } & \text { of } \\
\text { Enamel } & \end{array}$ & $\begin{array}{l}\text { Sibelli Parreiras, P } \\
\text { Vianna, Ad Loguercio, } \\
\text { Stella Kossatz , } \\
\text { Alessandra Reis.(2014) }\end{array}$ \\
\hline $\begin{array}{l}\text { Both concentrations of HP ( } 15 \text { or } 35 \%) \text {, } \\
\text { regardless of activated by an LED/laser } \\
\text { light, did not affect the surface } \\
\text { microhardness and had the same } \\
\text { effectiveness in enamel bleaching. }\end{array}$ & $\begin{array}{l}\text { Impact of hydrogen } \\
\text { peroxide activated by } \\
\text { lighting-emitting } \\
\text { diode/laser system on } \\
\text { enamel color and } \\
\text { microhardness: An in- }\end{array}$ & \begin{tabular}{lr} 
AnaBarbara & Araujo \\
Loiola, & Aline \\
Evangelista & Souza- \\
Gabriel , Silmara \\
Corona, RenataSiqueira \\
\multicolumn{2}{l}{ Scatolin.(2016) }
\end{tabular} \\
\hline
\end{tabular}


Volume 8 Issue 2 February 2020

\begin{tabular}{|c|c|c|}
\hline & situ design & \\
\hline $\begin{array}{l}\text { The effects of dental bleaching on the } \\
\text { pulp are not influenced by different } \\
\text { types of light, but different light } \\
\text { parameters can influence these } \\
\text { properties. There is insufficient } \\
\text { evidence about the influence of } \\
\text { different types of light on } \\
\text { inflammation/cytotoxicity of the pulp. }\end{array}$ & $\begin{array}{l}\text { Influence of different } \\
\text { types of light on the } \\
\text { response of the pulp } \\
\text { tissue in dental } \\
\text { bleaching: a systematic } \\
\text { review }\end{array}$ & $\begin{array}{lr}\text { Benetti } & \text {,Cleidiel } \\
\text { Aparecido Araujo } & \text { Aromos ,Marjorie De } \\
\text { Lemos } & \text { Gallinari, } \\
\text { Oliveira } & \text { Miyuki } \\
\text { Amanda } & \text { Terayama , André Luiz } \\
\text { Fraga Briso, Rogério } \\
\text { Jacinto,Gustavo Sivieri- } \\
\text { Araújo,Luciano } \\
\text { Cintra.(2017) }\end{array}$ \\
\hline $\begin{array}{l}\text { To compare an Er:YAG laser-activated } \\
\text { bleaching system with different light- } \\
\text { activated in-office bleaching systems } \\
\text { for color change, surface roughness, } \\
\text { and post-bleaching enamel bond } \\
\text { strength. }\end{array}$ & $\begin{array}{l}\text { In vitro comparison of an } \\
\text { Er:YAG laser-activated } \\
\text { bleaching system with } \\
\text { different light-activated } \\
\text { bleaching systems for } \\
\text { color change, surface } \\
\text { roughness, and enamel } \\
\text { bond strength }\end{array}$ & $\begin{array}{l}\text { Esra Ergin, } \\
\text { A. Ruya Yazici, } \\
\text { Berçem Kalender, } \\
\text { Aslihan Usumez, } \\
\text { Atilla Ertan, } \\
\text { Jale Gorucu, } \\
\text { Tugrul Sari.(2018) }\end{array}$ \\
\hline
\end{tabular}

\subsection{Principles of Teeth Whitening:}

When all is said in done teeth brightening works by treating the teeth with a specialist that could be dye-based. At that point, to accelerate the response, a blue light source is shone on the treated teeth.

Ultra Violet (UV) light has generally been utilized as the light source. Be that as it may, there are presently worries over the dangers of utilizing UV light. The UV light is a type of ionizing radiation which can cause the change of cells and possibly malignancy. This is of specific worry in the mouth because the oral tissues are exceptionally delicate [9].

\subsection{What Is LED Light?}

LED represents Light Emitting Diode. It is a gadget that discharges obvious light when provided with an electrical flow. Frequently the light is a solitary shading that can be anyplace among red and blue-violet on the noticeable light scale. Driven lights can be serious and regularly more brilliant than their halogen or radiant light partners. They are additionally significantly cooler as they have productive warmth disseminating plans [10].
LED lights needn't bother with a lot of intensity yet are profoundly proficient and keep going quite a while, especially in contrast with other light sources. They don't have a warm-up time, so they switch on at their most elevated force straight away. They are a type of obvious light, so they are not a sort of ionizing radiation, which implies they can't cause cell changes and consequently can't cause malignant growth. It is a more secure option in contrast to UV light for use in teeth brightening strategies.

\subsection{How Does LED Light Make Teeth Whiter?}

The LED light works close by a toothbrightening specialist. The light won't change the shade of your teeth whenever utilized alone. In any case, it goes about as an impetus to accelerate the responses when utilized with a brightening operator. The specialist is ordinarily hydrogen peroxide or carbamide peroxide, which are both dynamic fixings. Carbamide peroxide, for instance, is a moderate acting blanch that when applied to teeth will respond, separating into hydrogen peroxide and urea. Urea is a waste item, however, the hydrogen peroxide evacuates shallow stains and more 
Volume 8 Issue 2 February 2020

profound staining by changing their synthetic structure [11].

\section{METHODS AND MATERIALS}

\subsection{Designing of the device circuit:}

The designing of the device splits into three steps:

- First step: Designing a very simple two electronic circuits, one for controlling the intensity and one for time using capacitors, transistors, and potentiometer. Timing for the circuit controlled by the Arduino device and uses minutes for a time step-up for working on. Figure (1) shows the two proposed electronic circuits.

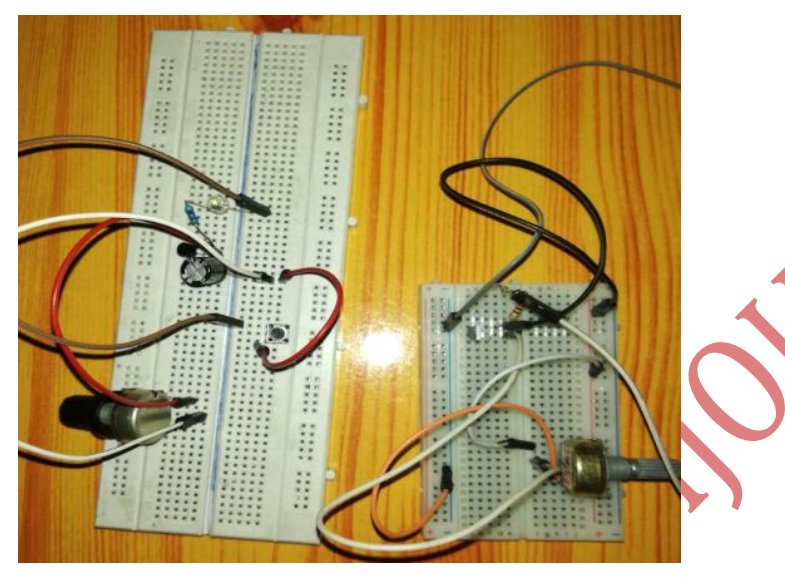

Fig 1: time and intensity volume circuit

Second step: converting these two analogue circuit into one digital circuit using Arduino to get different cases of intensity and time, as shown in figure (2).

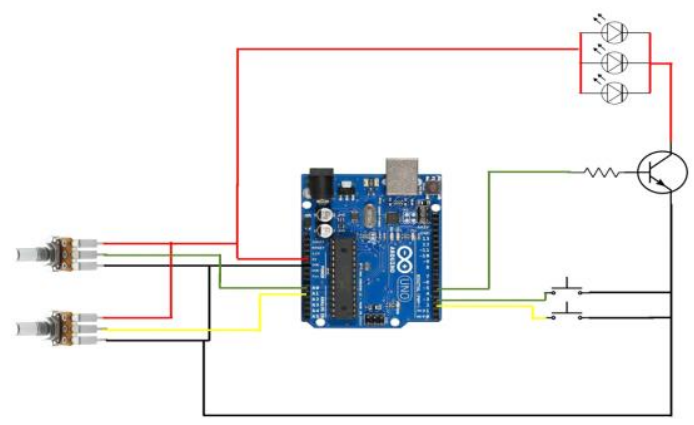

Fig 2: Circuit diagram of teeth whitening device

Third step: using a three-dimensional printer to make a box containing the component of the device that has a place for the led board, two control selector, and the operation button. This design makes the size of the device small and easy to use, as shown in figure (3).

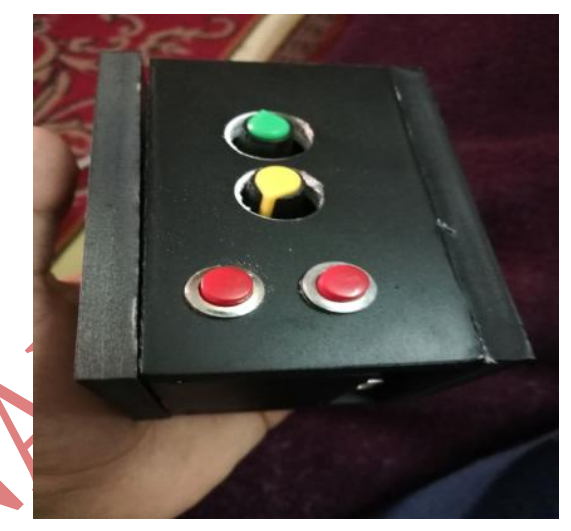

A) Front view of the device

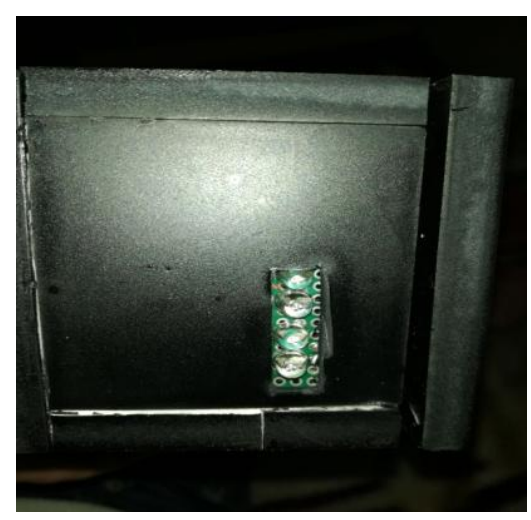

B) Back view of the device

Fig 3: Teeth whitening device

\subsection{MATERIALS of the Whitening}

Device:

It consists of the following parts: 


\section{- Whitening Agent}

The whitening agent is commonly hydrogen peroxide or carbamide peroxide, which are both active ingredients. Hydrogen peroxide is causing sensitivity and strain for teeth and gum when using a large percentage of it, such as $35 \%$, or $45 \%$. In this project we use a new type of paste, figure (4) which has hydrogen peroxide about $15 \%$, or $10 \%$, this type is safe and gives the same activity.

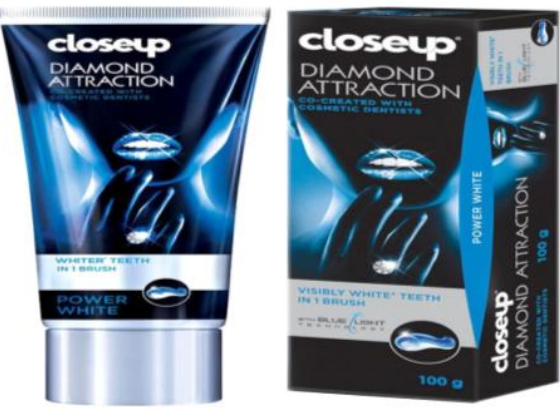

Fig 4: Whitening agent

\section{- Experimental procedure:}

Light Control: This part consists of the Arduino circuit that controls the shape and the time one of the whiting light signals through two selector buttons one for a time in minutes and the other bottom for selection the intensity in the lumen [12]. Thus, the experiment can control the time and intensity of whiting light.

Whiting Light Source: The whiting light source consist of eight normal blue LED. The blue LED safer for use because it doesn't cause any sensitivity, stain, and infection like another type of light.

Shade guide: Shade guide means any device used to match the color or shade of prefabricated artificial teeth to a patient's natural teeth for the specifications contained in a dentist's prescription for dentures or any other removable or fixed dental prosthetic device. This project will make a Special shade guide for this device from doing many measurements will explain in chapter four, The shade guide that used in this experiment shown in figure (5).
Volume 8 Issue 2 February 2020

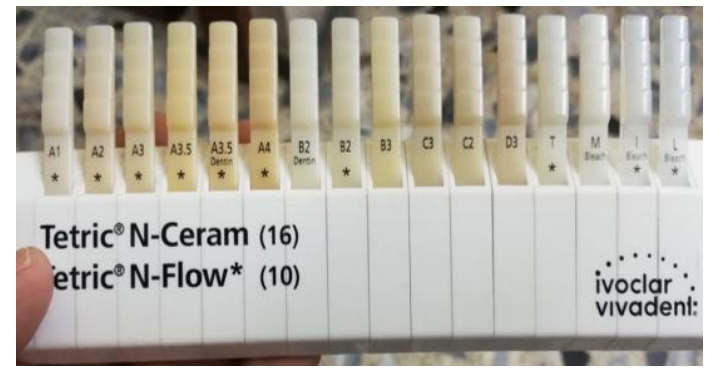

Fig 5: Teeth color shade guide

\subsection{Experimental Groups:}

The experiments did on artificial teeth for three groups ( A, B and C) with different discolored sources with Drink, smoke, and food. Each group has the same discolored sources but with different discolored times. These artificial teeth groups discolored with different sources for two days, two weeks and two months. Table (2) show the selected experiment groups.

Table 2. The selected experiments groups

\begin{tabular}{|c|c|c|c|}
\hline GROUP & DRINK & SMOKE & $\begin{array}{c}\text { FOOD } \\
\text { (CHOCOLATE) }\end{array}$ \\
\hline A & $\begin{array}{c}\text { TWO } \\
\text { DAYS }\end{array}$ & $\begin{array}{c}\text { TWO } \\
\text { DAYS }\end{array}$ & TWO DAYS \\
\hline B & TWO & TWO & TWO WEEKS \\
& WEEKS & WEEKS & \\
\hline C & TWO & TWO & TWO MONTHS \\
& MONTHS & MONTHS & \\
\hline
\end{tabular}

\subsection{The discoloration of teeth}

The experiments were done on an artificial tooth to make the whiting process sufficient enough for uses in a home. We use three samples of teeth and discoloration them in different ways some with drink, smoke, and food. These experiments lasted for different time to get discolored teeth, then toward the light on the teeth and measure the degree of whitening and draw a curve for the value, as shown in figure (6), figure (7) and figure (8). 
Volume 8 Issue 2 February 2020

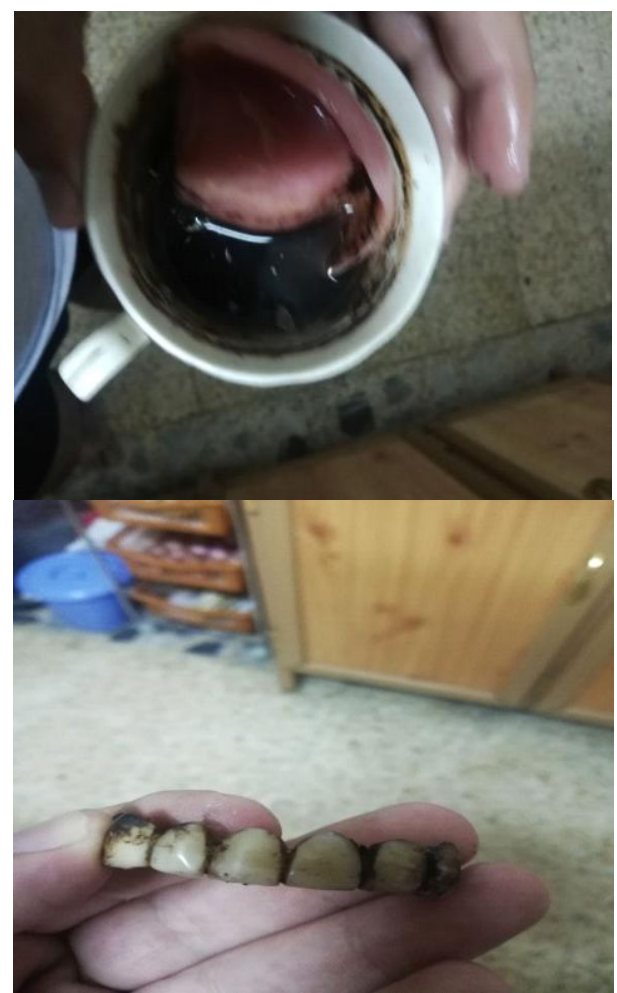

Fig 6: Discoloration of teeth by drink (coffee)

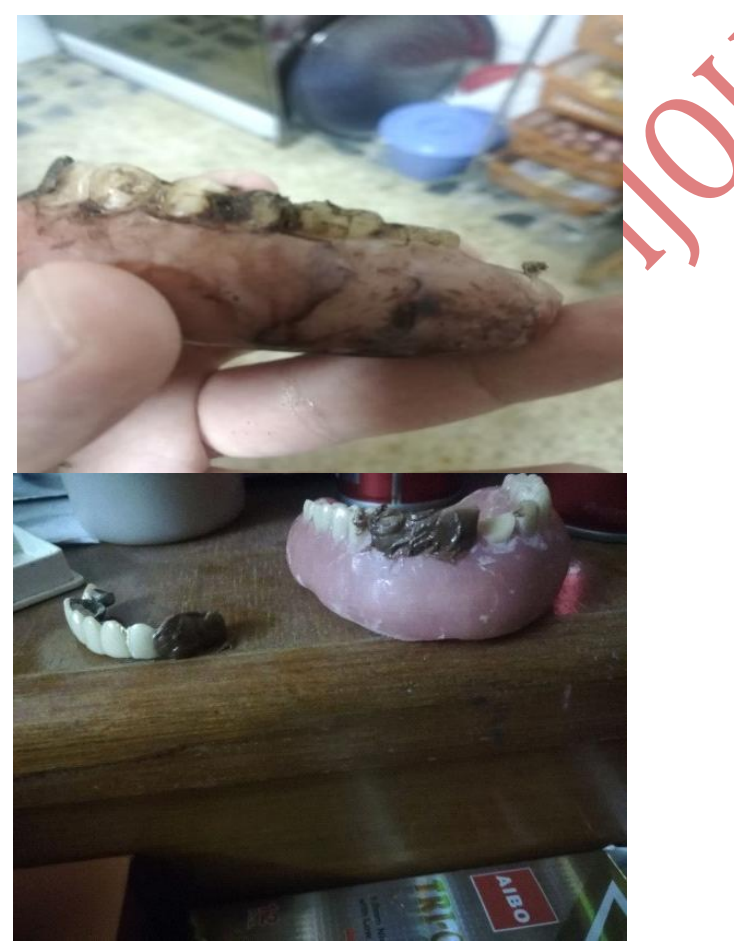

Fig7: Discoloration of teeth by food (chocolate).

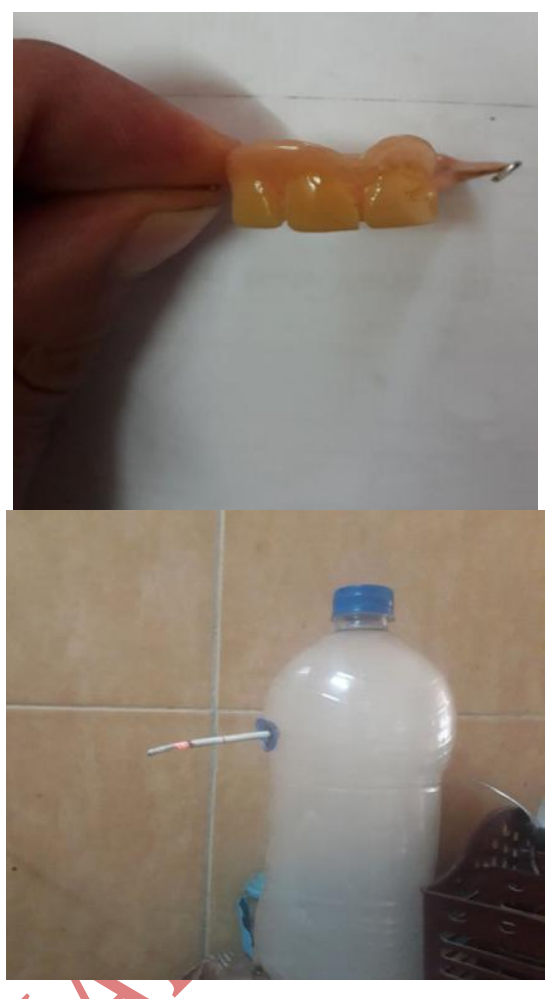

Fig 8: Discoloration of teeth by cigarette smokes.

\section{RESULT}

Depending on the experiments that had done (mentioned in chapter three), the following results had come out. Moreover, by using the shade guide to comparing the degree of whitening we got different results, which reported in this section.

\subsection{Setting teeth colored point (baseline tooth color):}

After discoloration of the teeth by factors (DRINK (COFFEE), SMOKE and FOOD (CHOCOLATE)) for two months as an example, we set the point of a degree of coloration depending on the shade guide.

\subsection{Staining artificial teeth with toothpaste}

In this part of the experiments, the toothpaste used to stain the artificial teeth, as shown in figure (9). 
whitening light from the proposed whitening teeth device.

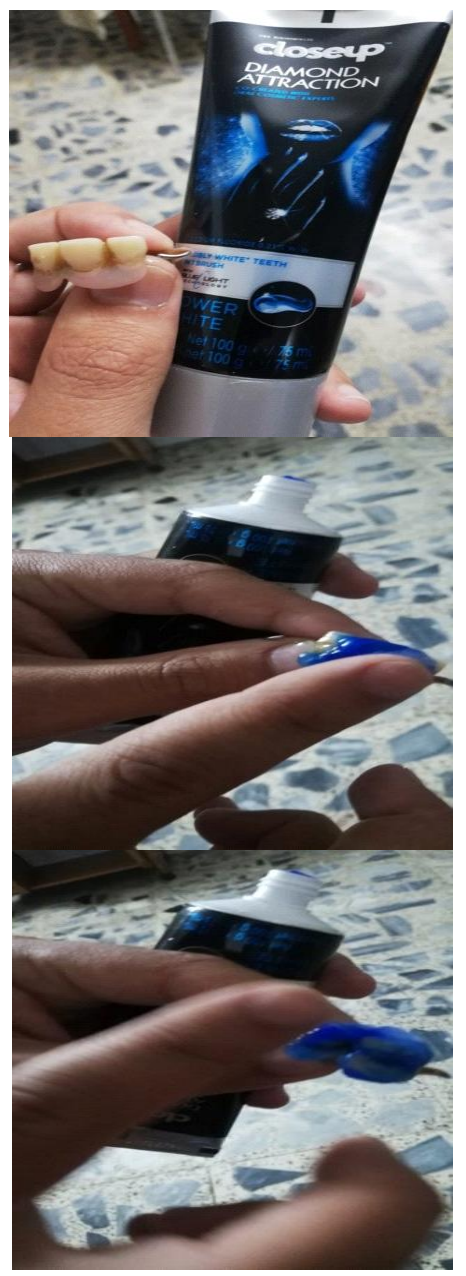

Fig 9: Staining teeth with toothpaste

\subsection{The use of whitening device}

After staining teeth with toothpaste, it is time for our device to bleaching the teeth. We did many tests on artificial teeth for bleaching them (took different time). Every test we did it on our teeth has differed from the test which followed by (intensity and time). For example, one time we fixed the time and changed the intensity (we measured the intensity value by "Light Meter") and one time by fixing intensity and changing the time. Figure (10) shows the technique of exposing artificial teeth to the light produced from the proposed whitening teeth device. Moreover, figure (11) shows the treated or bleached artificial teeth after exposure to the

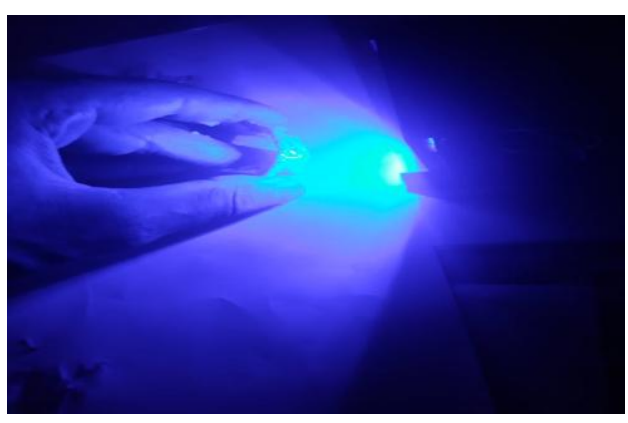

Fig 10: The bleaching artificial teeth by the proposed whitening device

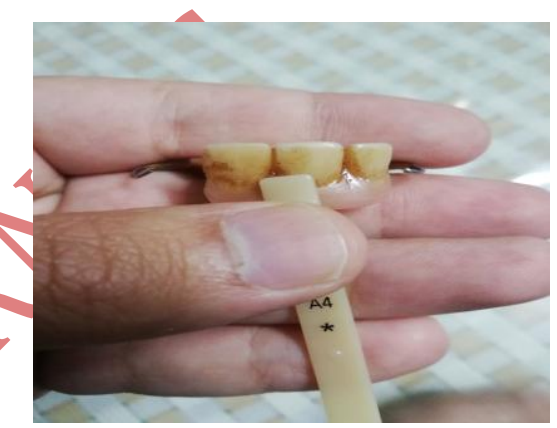

Fig 11: The treated or bleached artificial teeth.

After many tests and experiments, visual and experimental color changes by groups at different time points are summarized in Tables (3, 4 \& 5) for food (Chocolate), smoking and drink (coffee) discolored respectively. Baseline color parameters of the three groups were not different with the visual and the experimental methods.

Table 3. The parameters of whitening device and results for food (Chocolate) discolored

\begin{tabular}{|c|c|c|}
\hline Time & Intensity & Shade guide \\
\hline 3 & $3.4 \pm 0.22$ & A4 \\
\hline 3.5 & $3.2 \pm 0.31$ & A3.5 \\
\hline 4 & $3 \pm 0.33$ & A3 \\
\hline 4.5 & $2.8 \pm 0.24$ & D3 \\
\hline 5 & $2.6 \pm 0.32$ & B3 \\
\hline 5.5 & $2.4 \pm 0.42$ & B2 \\
\hline
\end{tabular}




\begin{tabular}{|c|c|c|}
\hline 6 & $2.2 \pm 0.44$ & B2 dentin \\
\hline 6.5 & $2 \pm 0.25$ & A2 \\
\hline 7 & $2 \pm 0.25$ & A1 \\
\hline 7.5 & $2 \pm 0.25$ & T \\
\hline
\end{tabular}

Table 4. The parameters of the whitening device and results for smoke

\begin{tabular}{|c|c|c|}
\hline Time & Intensity & Shade guide \\
\hline 3 & $3.4 \pm 0.22$ & $\mathrm{~A} 4$ \\
\hline 3.5 & $3.2 \pm 0.31$ & $\mathrm{~A} 4$ \\
\hline 4 & $3 \pm 0.33$ & $\mathrm{~A} 3.5$ \\
\hline 4.5 & $2.8 \pm 0.24$ & $\mathrm{D} 3$ \\
\hline 5 & $2.6 \pm 0.32$ & $\mathrm{C} 2$ \\
\hline 5.5 & $2.4 \pm 0.42$ & $\mathrm{C} 3$ \\
\hline 6 & $2.2 \pm 0.44$ & $\mathrm{~B} 3$ \\
\hline 6.5 & $2 \pm 0.25$ & $\mathrm{~B} 2$ \\
\hline 7 & $2 \pm 0.25$ & $\mathrm{~B} 2$ dentin \\
\hline 7.5 & $2 \pm 0.25$ & $\mathrm{~A} 2$ \\
\hline
\end{tabular}

Table 5. The parameters of the whitening device and results for a drink (coffee) discolored

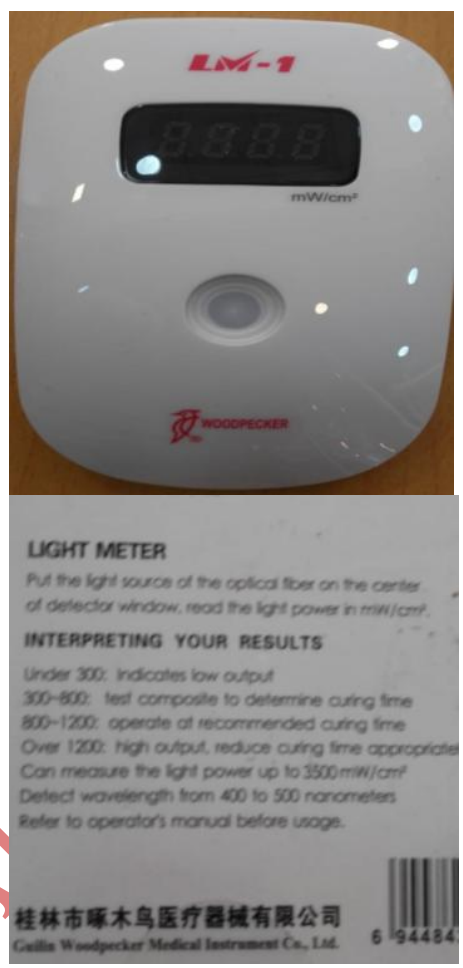

\begin{tabular}{|c|c|c|}
\hline Time & Intensity & Shade guide \\
\hline 3 & $3.4 \pm 0.22$ & $\mathrm{D} 3$ \\
\hline 3.5 & $3.2 \pm 0.31$ & $\mathrm{C} 2$ \\
\hline 4 & $3 \pm 0.33$ & $\mathrm{C} 3$ \\
\hline 4.5 & $2.8 \pm 0.24$ & $\mathrm{~A} 3.5$ \\
\hline 5 & $2.6 \pm 0.32$ & $\mathrm{~A} 3$ \\
\hline 5.5 & $2.4 \pm 0.42$ & $\mathrm{~B} 3$ \\
\hline 6 & $2.2 \pm 0.44$ & $\mathrm{~A} 2$ \\
\hline 6.5 & $2 \pm 0.25$ & $\mathrm{~B} 2$ \\
\hline 7 & $2 \pm 0.25$ & $\mathrm{~B} 2$ dentin \\
\hline 7.5 & $2 \pm 0.25$ & A1 \\
\hline
\end{tabular}

Fig 12: LED intensity meter.

According to the results of the experiment, changing the intensity had more effect on teeth brightness than changing the time. Figure (13) show the relationship between time and intensity for brightness.

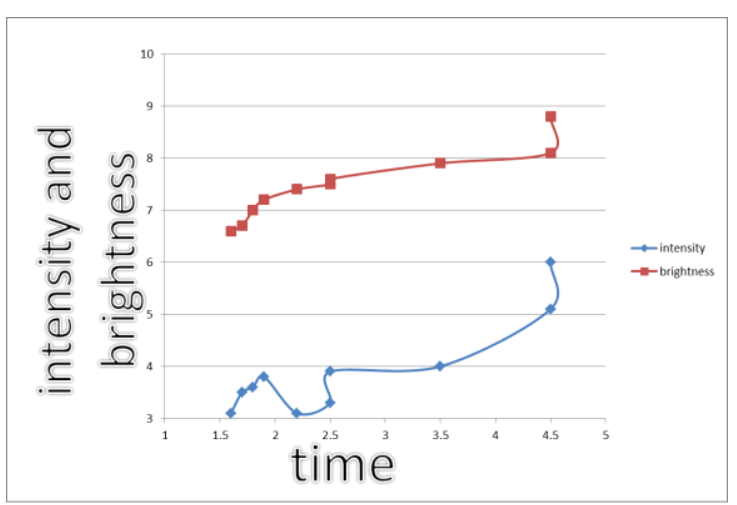

Fig 13: The relationship of time and intensity for brightness The calibration of the device and measuring the brightness done using a light-curing intensity measuring device, which shown in figure (12).

- Intensity: measured by lumen.

- Time: measured by minute.

- Brightness: indicates the lightness or darkness of a color in relation to a neutral greyscale, which extends from absolute black (value symbol 0) to absolute white (value symbol 10). This is essentially how 'bright' the color is. 
Volume 8 Issue 2 February 2020

\section{Discussion}

In this study, the in-house bleaching technique showed a significant change in the lightness of the artificial teeth compared with the 2-day, 2- week and 2-month observations. The experiments at the house bleaching system were done by a lightactivated system using the LED as a bleaching accelerator. It has been stated that the LED is the most favorable light source as it emits blue light. Moreover, using a normal and cheap available toothpaste provides a very good result. However, with high energy that stimulates the breakdown of hydrogen peroxide without heat production. With the help of the LED and the presence of ferrous gluconate as a photoinitiator as an ingredient in the toothpaste, it accelerates the process of breakdown of hydrogen peroxide in the presence of light.

The results show that the time and the intensity of the LED light are essential parameters for bleaching the artificial teeth. Moreover, these parameters (time and intensity) were related to each other in reverse relation to getting sufficient results for brightening the teeth.

The results reported in tables (3, 4 and 5) give us an indicator that the light drinks like coffee had less time and less intensity to reach for good results of whiting our teeth. While smoking indicates that it hard or maybe impossible to get good whiting teeth results with the proposed whiting system or any bleaching system.

This study got out with the results and conclusion that matches with many other studies in the field of time and intensity of the bleaching process [13-15].

\section{CONCLUSIONS}

Everyone needs to look good and the first thing we notice on people is their smile. Thus, the teeth are very important parts of our smile we need to take care of it so our device provides maintenance and whitening the teeth with low cost and without harmful effects when you are sitting at our homes. In conclusion, within the limitations of the current study, our tested bleaching technique showed almost similar clinical efficiency or effect using regular toothpaste. Moreover, the whiting time was limited to be less than other clinical teeth whiting devices.

\section{References}

[1] E. A. A. Neel, A. Aljabo, A. Strange, S. Ibrahim, M. Coathup, A. M. Young, et al., "Demineralizationremineralization dynamics in teeth and bone," International journal of nanomedicine, vol. 11, p. 4743, 2016.

[2] J. Morrier, "White spot lesions and orthodontic treatment. Prevention and treatment," L'Orthodontie francaise, vol. 85, pp. 235-244, 2014.

[3] F. Marson, L. Sensi, L. Vieira, and E. Araújo, "Clinical evaluation of inoffice dental bleaching treatments with and without the use of light-activation sources," Operative dentistry, vol. 33, pp. 15-22, 2008.

V. Vennila, V. Madhu, R. Rajesh, K. K. R. Ealla, S. R. Velidandla, and S. Santoshi, "Tetracycline-induced discoloration of deciduous teeth: case series," Journal of international oral health: JIOH, vol. 6, p. 115, 2014.

[5] J. P. Griffin and P. F. D'Arcy, A manual of adverse drug interactions: Elsevier, 1997.

[6] C. M. Carey, "Tooth whitening: what we now know," Journal of Evidence Based Dental Practice, vol. 14, pp. 7076, 2014.

[7] L. K .Bakland and J. O. Andreasen, "Dental traumatology: essential diagnosis and treatment planning," Endodontic topics, vol. 7, pp. 14-34, 2004.

[8] D. G. Deak and J. Lam, "Photon energy conversion structure," ed: Google Patents, 2009.

[9] K. Baroudi and N. A .Hassan, "The effect of light-activation sources on tooth bleaching," Nigerian medical 
journal: journal of the Nigeria Medical Association, vol. 55, p. 363, 2014.

[10] S. Nakamura, S. Pearton, and G. Fasol, "The blue laser diode. The complete story," ed :IOP Publishing, 2001.

[11] L.-B. He, M.-Y. Shao, K. Tan, X. Xu, and J.-Y. Li, "The effects of light on bleaching and tooth sensitivity during in-office vital bleaching: a systematic review and meta-analysis," Journal of dentistry, vol. 40, pp. 644-653, 20.12

[12] O. Zuabi, "Teeth whitening with $6 \%$ hydrogen peroxide vs. $35 \%$ hydrogen peroxide, a comparative controlled study," Refu'at ha-peh veha-shinayim (1993), vol. 32, pp. 38-44, 62, 2015.

[13] I. F. I. Abouelfotouh, O. M. I. Fahmy, A. E. Khairy, and D. M. Salah, "A comparative study of different bleaching techniques, regarding the color change, stability and postoperative hypersensitivity: a randomized controlled clinical trial," 2018.

[14] S. Kwon, M. Meharry, U. Oyoyo, and Y. Li, "Efficacy of do-it-yourself whitening as compared to conventional tooth whitening modalities: an in vitro study," Operative dentistry, vol. 40, pp. E21-E27, 2015.

[15] P. Dawson, M. Sharif, A. Smith, and P. Brunton, "A clinical study comparing the efficacy and sensitivity of home vs combined whitening," Operative dentistry, vol. 36, pp. 460-466, 2011. 